This is an electronic reprint of the original article. This reprint may differ from the original in pagination and typographic detail.

Author(s): Laajalahti, Anne

Title: Kriisiviestinnästä kriisivuorovaikutukseen : puheviestinnän näkökulmia kriiseissä ja kriiseistä viestimiseen

Year: $\quad 2016$

Version:

Please cite the original version:

Laajalahti, A. (2016). Kriisiviestinnästä kriisivuorovaikutukseen : puheviestinnän näkökulmia kriiseissä ja kriiseistä viestimiseen. Prologi : puheviestinnän vuosikirja 2016, 2016, 76-82.

All material supplied via JYX is protected by copyright and other intellectual property rights, and duplication or sale of all or part of any of the repository collections is not permitted, except that material may be duplicated by you for your research use or educational purposes in electronic or print form. You must obtain permission for any other use. Electronic or print copies may not be offered, whether for sale or otherwise to anyone who is not an authorised user. 


\title{
Puheenvuoro
}

\section{Kriisiviestinnästä kriisivuorovaikutukseen}

\section{Puheviestinnän näkökulmia kriiseissä ja kriiseistä viestimiseen}

\author{
Anne Laajalahti \\ tutkijatohtori, FT \\ Jyväskylän yliopisto \\ anne.laajalahti@jyu.fi
}

\section{Tiivistelmä}

Kriisiviestintää on tarkasteltu jo melko runsaasti esimerkiksi journalistiikan, mediatutkimuksen ja yhteisöviestinnän aloilla. Puheviestinnässä kriisiviestintään on sen sijaan kiinnitetty vähemmän huomiota. Tuon puheenvuorossani esille erilaisia tapoja, joilla puheviestinnän näkökulmia voitaisiin soveltaa kriisiviestinnän tutkimuksessa ja opetuksessa. Esittelen ideoita, miten kriiseissä ja kriiseistä viestimistä voitaisiin kehittää puheviestinnällistä ymmärrystä hyödyntämällä. Lisäksi ehdotan kriisivuorovaikutuksen käsitteen nostamista kriisiviestinnän käsitteen rinnalle. Puheenvuoro perustuu työskentelyyni kriisiviestinnän - tai kriisivuorovaikutuksen - tutkijana ja opettajana vuodesta 2012 lähtien. Esittelen ensin lyhyesti puheviestinnän lähtökohdista tekemääni kriisiviestinnän tutkimusta sekä kaksi suunnittelemaani ja toteuttamaani kriisiviestinnän opintokokonaisuutta. Sen jälkeen kokoan yhteen ja jäsennän kriisiviestinnän tutkijana työskennellessäni, opetuksia suunnitellessani, opiskelijoiden kanssa keskusteluja käydessäni ${ }^{1}$ sekä heidän kurssitöitään lukiessani eteeni tulleita ajatuksia siitä, mitä annettavaa puheviestinnällä voisi olla kriisiviestinnälle. Käyn läpi erilaisia puheviestinnälle tyypillisiä käsitteitä, teorioita ja teoreettisia jäsennyksiä, jotka vaikuttavat erityisen otollisilta kriisiviestinnän tutkimukseen ja opetukseen sovellettaviksi. Tarkoituksenani on näin edistää kriisiviestinnän tutkimusta puheviestinnän näkökulmista tarjoamalla Prologin lukijoille ideoita ja konkreettisia esimerkkejä mahdollisista tutkimuskohteista. Puheenvuoroni lopussa pohdin, miten olen kokenut puheviestinnän tarkastelutasojen soveltamisen kriisiviestinnän kontekstiin. Samalla puheenvuoroni tarkoituksena on innostaa puheviestinnän tutkijoita, opettajia ja opiskelijoita havaitsemaan puheviestinnän merkitys ja hyöty yhä uudelleen uusissa tai ainakin vähemmän käsitellyissä yhteyksissä ja täten kannustaa puheviestijöitä ylittämään tutkimusalueiden rajoja ja soveltamaan asiantuntemustaan yhä uusien kontekstien tarkastelussa.

ASIASANAT: kriisiviestintä, kriisiviestintäosaaminen, kriisivuorovaikutus, puheviestinnän opetus, puheviestinnän tutkimus 


\section{Johdanto}

Kriisi on erityinen uhkaava tilanne tai tapahtumasarja, jolle on ominaista yllätyksellisyys ja ennakoimattomuus, joka aiheuttaa huomattavaa epävarmuutta ja joka vaatii nopeaa reagointia (ks. esim. Ulmer, Sellnow \& Seeger 2015, 8). Kriisiviestinnän tutkimusalueella on tarkasteltu monenlaisia kriisejä, kuten organisaation mainekriisejä, luonnonkatastrofeja, suuronnettomuuksia, pandemioita, poliittisia kriisejä ja terrorismia. Kriisit voivat olla joko tahattomia tai tahallisesti aiheutettuja ja liittyä esimerkiksi turvallisuuteen, talouteen, politiikkaan, yhteiskunnallisiin olosuhteisiin sekä luontoon ja ympäristöön. Näin ollen ne voivat koskettaa ketä tahansa ihmisistä.

Kirjallisuudessa on keskitytty usein tarkastelemaan organisaatioiden yksisuuntaista, ylhäältä alaspäin (top-down) suuntautuvaa kriisiviestintää (Taylor \& Perry 2005). Kriisiviestintä voidaan kuitenkin jakaa neljään tyyppiin: 1) organisaatioiden ja viranomaisten keskinäiseen viestintään, 2) organisaatioiden viestintään kansalaisille ja muille sidosryhmilleen, 3) kansalaisten keskinäiseen viestintään sekä 4) kansalaisten viestintään organisaatioiden ja viranomaisten suuntaan (Reuter, Marx \& Pipek 2012). Kriisiviestintä voidaan jakaa myös viestintään ennen kriisejä, kriisien aikana ja kriisien jälkeen (Coombs 2015; Fearn-Banks 2011; Reynolds \& Seeger 2005). Tässä puheenvuorossa hahmotan, että kriisiviestintä on kaikkea sitä vuorovaikutusta, jota tarvitaan eri tahojen kesken niin kriiseihin varautumisessa ja niiden estämisessä, kriisien hallinnassa ja kriiseihin reagoinnissa kuin kriiseistä toipumisessa ja oppimisessa.

Kriisiviestintää on tarkasteltu jo melko runsaasti esimerkiksi journalistiikassa, mediatutkimuksessa ja yhteisöviestinnässä. Puheviestin- nässä kriisiviestintään on sen sijaan kiinnitetty vähemmän huomiota. ${ }^{2}$ Tämän puheenvuoron tavoitteena on tuoda esiin erilaisia tapoja ja ideoita, joilla puheviestinnälle tyypillisiä tarkastelutasoja, käsitteitä ja teorioita voitaisiin soveltaa kriisiviestinnän tutkimuksessa ja opetuksessa.

\section{Puheviestintää kriisiviestinnän tutkimukseen ja opetukseen}

Kiinnostuin kriisiviestinnästä työskennellessäni vuosina 2012-2014 Jyväskylän yliopiston yhteisöviestintä-oppiaineessa kahdessa kansainvälisessä EU:n rahoittamassa FP7-tutkimushankkeessa: 1) Public Empowerment Policies for Crisis Management (PEP) ja 2) CBRN crisis management: Architecture, Technologies and Operational Procedures (CATO) ${ }^{3}$. PEP-hankkeen tavoitteena oli selvittää, miten kansalaisten kriisienhallintakykyä voitaisiin tehostaa ja mitkä menettelytavat toimivat parhaiten kansalaisten voimaannuttamiseksi. CATO-hanke keskittyi sen sijaan epäkonventionaalisia aseita ja CBRN-materiaaleja (chemical, biological, radiological, nuclear) hyödyntävien terrorismitilanteiden tarkasteluun. Työskentely näissä yhteisöviestinnän kriisiviestintähankkeissa antoi minulle kimmokkeen ja mahdollisuuden soveltaa puheviestinnän näkökulmia kriisiviestinnän tutkimukseen, ja sainkin sisällyttää PEP-hankkeen aineistonkeruisiin myös omia kiinnostuksen kohteitani. Koska oma taustani oli puheviestinnässä ja väitöskirjani liittyi vuorovaikutusosaamiseen (Laajalahti 2014), keräsimme aineistoa myös kriisiviestinnän ammattilaisten ja kansalaisten kriiseissä tarvitsemasta vuorovaikutusosaamisesta, jota aloimme kutsua kriisiviestintäosaamiseksi (crisis communication competence) (Laajalahti, Hyvärinen \& Vos 2015; 2016). 
Olen saanut pohtia ja soveltaa puheviestinnän näkökulmia kriiseissä ja kriiseistä viestimiseen myös suunnitellessani ja pitäessäni erilaisia kriisiviestinnän luentoja ja opintokokonaisuuksia. Tämä puheenvuoro pohjautuu niistä erityisesti seuraaviin kahteen:

Puheviestinnän näkökulmia kriisiviestintään (5 op): Helsingin yliopisto, puheviestinnän syventävät opinnot, kevät 2015

\section{Crisis communication and mana-} gement: theoretical perspectives, actual cases (4 tuntia): Artevelde University College Ghent, Belgium, Department of Communication Management and Journalism, vierailu kurssilla Government communication pääaineessa Communication management, syksy 2015.

Opintojaksoilla käsiteltiin kriisiviestinnän ja kriisien hallinnan/johtamisen perusteita sekä keskeisimpiä teorioita ja pohdittiin puheviestinnän ja kriisiviestinnän yhteyksiä. Mitä kriisiviestintä on tai mitä se voisi olla puheviestinnän ammattilaisen työssä? Miten puheviestintä liittyy erilaisiin kriiseihin, niissä tai niistä viestimiseen sekä niiden hallintaan/johtamiseen? Erityistä huomiota kiinnitettiin vuorovaikutusosaamisen ja oppimisen kysymyksiin.

Opiskelijat pohtivat molemmilla opintojaksoilla oman puheviestinnällisen asiantuntijuutensa ja kriisiviestinnän yhteyksiä niin valmiiksi annettujen kuin heidän itse keksimiensä esimerkkien kautta. Lisäksi opiskelijat ideoivat ja suunnittelivat kuvitteellisia tutkimuksia ja koulutuksia, joissa he sovelsivat puheviestinnän tietämystään kriisiviestinnän kontekstiin. Helsingin yliopistossa pienryhmissä ideoidut ja koko ryhmälle esitellyt tutkimukset ja koulutukset saattoivat liittyä mihin tahansa kriisiviestinnän osa-alueeseen. Arteveldessä esimerkkinä käytettiin sen sijaan Pariisin iskujen ${ }^{4}$ jälkeistä terroristien etsimistä ja paikallisten ulkonaliikkumiskieltoa Brysselissä 21.-25.11.2015 eli nk. "Brussels lockdownia"5 sekä tapahtumiin liittynyttä Twitter-toimintaa ${ }^{6}$.

\section{Kriisiviestintäosaaminen ja muita sovelluskohteita}

Kokoan seuraavaksi yhteen puheviestinnän näkökulmia ja tarkastelutasoja - käsitteitä, teorioita ja teoreettisia jäsennyksiä -, jotka vaikuttavat erityisen otollisilta kriisiviestinnän tutkimukseen ja opetukseen sovellettaviksi. Koonti perustuu kriisiviestinnän tutkijana ja opettajana tekemiini havaintoihin sekä kriisiviestinnän opintokokonaisuuksilla opiskelijoiden kanssa käymiini keskusteluihin. Tarkoituksenani ei ole esittää kattavaa koontia eikä väittää, ettei mitään seuraavista aiheista olisi vielä tutkittu. Sen sijaan tarkoituksenani on jakaa niitä oivalluksia ja iloa tuottaneita ideoiden aihioita, jotka ovat tehneet minun, puheviestijän, mielestä kriisiviestinnän pohtimisesta erityisen antoisaa ja jotka kaipaisivat mielestäni vielä puheviestinnällistä lisätarkastelua. Koonnin tarkoituksena on edistää kriisiviestinnän tutkimusta puheviestinnän näkökulmista tarjoamalla Prologin lukijoille virikkeitä ja esimerkkejä siitä, millaista tutkimusta kriisiviestinnän kentälle kaivattaisiin.

Interpersonaalinen viestintä ja vuorovaikutussuhteet. Kriisiviestinnän tutkimus ei ole kohdistunut usein ihmisten välisen vuorovaikutuksen tai vuorovaikutussuhteiden tarkasteluun. Miten erilaisia työ- ja yksityiselämän vuorovaikutussuhteita luodaan, ylläpidetään ja kehitetään kriisiviestinnän kontekstissa? Miten kriisit muovaavat jo olemassa olevia suhteita? Kriisiviestinnän kentällä on monia ammatillisia, niin symmetrisiä kuin asymmetrisiä, työelämän vuorovaikutussuhteita sekä kollaboratiivisia yhteistyösuhteita eri toimijoiden kesken, joi- 
den tarkastelu puheviestinnän näkökulmista voisi syventää ymmärrystä kriisiviestinnästä. Esimerkiksi luottamuksen (uudelleen) rakentuminen johtajan ja johdettavien välillä organisaation mainekriisin jälkeen on aihe, josta käsin ammatillisia vuorovaikutussuhteita voisi tarkastella kriisiviestinnän kontekstissa. Mielenkiintoisia tutkimuskohteita löytyisi myös läheisten vuorovaikutussuhteiden parista. Tutkimusten mukaan monet kansalaiset luottavat kriisitilanteissa ja riskejä arvioidessaan jopa viranomaisia enemmän itselleen läheisiin ihmisiin (ks. esim. Haataja, Hyvärinen \& Laajalahti 2014, 148; Hargittai ym. 2010). Ihmisten riskikäsityksiä on usein tarkasteltu yksilökognitiivisella tasolla, mutta kiinnostavaa olisi myös tutkia riskejä läheisissä vuorovaikutussuhteissa yhdessä neuvoteltuina sosiaalisen merkityksenannon ilmiöinä. Jaettujen riskikäsitysten lisäksi puheviestinnän tutkimus voisi kohdistua esimerkiksi perhesuhteisiin sen yhteydessä, mitä ja miten lapsille kerrotaan terrori-iskuista.

Ryhmäviestintä. Kriisiviestintä ja kriisien hallinta/johtaminen tapahtuu usein erilaisissa ryhmissä ja tiimeissä. Kriisiviestintä kaipaa kuitenkin vielä syvällisempää teoreettista hahmottelua ryhmäviestinnän tasolla. Puheviestinnän ymmärrys voisi auttaa ymmärtämään entistä paremmin ryhmien muodostumista, rakennetta ja dynamiikkaa sekä erilaisia ryhmäviestinnän ilmiöitä ja prosesseja, kuten ryhmien päätöksentekoa, ongelmanratkaisua ja ryhmäajattelua kriisitilanteissa. Myös esimerkiksi neuvottelun, konfliktien, vallankäytön, sovittelemisen ja hajautettujen tiimien tutkimuksen soveltaminen kriisiviestinnän kontekstiin voisi olla tulevaisuudessa antoisaa.

Medioitu puheviestintä ja esiintyminen. Kriisit koskevat usein suurta joukkoa ihmisiä, ja paikallisetkin kriisit muuttuvat monesti globaaleiksi mediatapahtumiksi. Osa kriiseistä, kuten osa mainekriiseistä, myös saa alkunsa ja elää elämänsä pääsääntöisesti mediassa. Puheviestintä voisi auttaa ymmärtämään mediaesiintymisen erityispiirteitä sekä vuorovaikutteisen verkkoviestinnän ja sosiaalisen median lähtökohtia, muotoja ja mahdollisuuksia kriisitilanteissa. Kriisit haastavat niin viranomaisten, kriisiviestinnän ammattilaisten ja toimittajien kuin tavallisten kansalaisten mediakompetenssia. Esimerkiksi sosiaalisen median hyödyntämistä ja monitorointia kriisiviestintätilanteissa on jo tutkittu jonkin verran (ks. koontia esim. Ruggiero \& Vos 2014). Puheviestinnän ymmärrys voisi kuitenkin syventää tätä keskustelua esimerkiksi verkkokeskusteluihin osallistumisen, yhteisöihin kiinnittymisen ja identifioitumisen sekä vuorovaikutuksen etiikan näkökulmista.

Vuorovaikutuksen teoriat. Monet puheviestinnässä käytetyt teoriat vaikuttavat otollisilta sovellettaviksi kriisiviestinnän tarkasteluun. Koska kriisit luovat lähtökohtaisesti epävarmuutta, voisi kriisiviestinnän tutkiminen esimerkiksi Charles Bergerin epävarmuuden vähentämisen teorian (uncertainty reduction theory) näkökulmasta olla antoisaa. Kriisiviestinnän kohdentamista ja sopivuutta voisi sen sijaan lähestyä esimerkiksi Howard Gilesin ja kumppaneiden viestinnän mukauttamisen/mukautumisen teorian (communication accommodation theory) näkökulmasta. Vuorovaikutussuhteita ja niiden dynamiikkaa kriisiviestinnässä voisi tarkastella sen sijaan esimerkiksi Leslie Baxterin ja Barbara Montgomeryn vuorovaikutussuhteen jännitteiden teorian (relational dialectics) tai George Graenin ja kumppaneiden johtaja-alaissuhteen vaihdantateorian (leader-member exchange theory) kannalta. Kriisiviestinnän lähestyminen erilaisista puheviestinnälle tyypillisistä teorioista käsin voisi auttaa ymmärtämään ja teoretisoimaan kriisiviestintää uusilla tavoilla yli yksittäisten tapaustutkimusten, joskaan jako teoreettisen ja empiirisen tutkimuksen välillä ei 
ole yksiselitteinen (Jensen 2014; Ojala \& Saikkonen 2014).

Argumentaatio, retoriikka ja vaikuttaminen. Kriisiviestinnän tavoitteena on usein johonkin vaikuttaminen, olipa kyseessä sitten vaikkapa yrityksen asiakkaiden tai muiden sidosryhmien mielipiteisiin vaikuttaminen mainekriisin jälkeen, poliittisten tarkoitusperien ajaminen sodankäynnin yhteydessä tai ihmisten käyttäytymiseen vaikuttaminen uhkaavan pandemian ennaltaehkäisyssä. Puheviestintä voisi syventää ymmärrystä vaikuttamisen ja argumentoinnin keinoista kriisiviestinnässä. Myös kriisiviestinnän retorinen analyysi, kuten lausumien muotoilun ja yleisösuhteen tarkastelu, voisi yhdistää puheviestinnän tarkastelutasoja kriisiviestinnän kontekstiin.

Tunteet, supportiivinen viestintä ja sosiaalinen tuki. Kriisiviestinnän tutkimus on keskittynyt usein eri toimijoiden tiedontarpeisiin, tiedon etsimiseen ja tehokkaaseen tiedon jakamiseen (ks. esim. Austin, Liu \& Jin 2012; Haataja, Hyvärinen \& Laajalahti 2014). Kriisiviestintä ei kuitenkaan rajoitu ilmiönä vain kognitiiviseen tietoaspektiin: kriisitilanteet herättävät ihmisissä myös monenlaisia tunteita, joiden huomioiminen on kriisiviestinnässä ja kriisien hallinnassa/johtamisessa tärkeää (ks. lisäksi Laajalahti, Hyvärinen \& Vos 2016, 9). Näin ollen esimerkiksi puheviestinnän ymmärrys supportiivisesta viestinnästä ja sosiaalisesta tuesta voisi osaltaan syventää kriisiviestinnän tutkimuksen ja opetuksen kenttää. Myös esimerkiksi kuuntelemisen, empatian osoittamisen sekä vuorovaikutuksen ja hyvinvoinnin yhteyksien tarkastelu puheviestinnän näkökulmista olisi tervetullutta kriisiviestinnän kentälle.

Vuorovaikutusosaaminen ja oppiminen. Vaikka viestintään ja vuorovaikutukseen liittyvät osaamisvaatimukset ovat useissa kriisiviestinnän tutkimuksissa implisiittisesti läsnä, vuorovaikutusosaamisen käsitettä ja tutkimustraditiota on harvemmin sovellettu kriisiviestinnän kontekstiin (Laajalahti, Hyvärinen \& Vos 2016, 3). Esimerkiksi työyhteisöviestinnän tarkastelu vuorovaikutusosaamisen ja osaamisen kehittymisen/kehittämisen näkökulmasta erilaisissa turvallisuuskriittisissä organisaatioissa, joissa henkilöiden ja ympäristön turvallisuuden varmistaminen on erityisen keskeistä, olisi kuitenkin jatkossa tarpeen. Myös esimerkiksi kriisitilanteissa työskentelevien toimittajien vuorovaikutusosaamisen tutkiminen olisi tulevaisuudessa tärkeää; edellyttäähän esimerkiksi surun keskellä ja mahdollisesti sokissa olevien haastateltavien kunnioittava kohtaaminen, yhteistyö kriisiviestinnän ammattilaisten kanssa sekä kilpailun ja yhteistyön välinen jännite toisten toimittajien kanssa toimittajilta erityistä vuorovaikutusosaamista. Vuorovaikutusosaamisen vaatimusten, edellytysten, oppimisen ja tukemisen ymmärtäminen voisi osaltaan auttaa kehittämään eri osapuolten välistä kriisiviestintää ja kriisien hallintaa/johtamista.

\section{Kriisiviestinnästä kriisivuorovaikutukseen?}

Ludwig Wittgensteinin tunnetun lausahduksen mukaan "kieleni rajat ovat maailmani rajat". Ajatuksena on siis, ettemme voi tietää mitään, mille meillä ei ole sanoja. Sanat ja kieli eivät pelkästään neutraalisti heijasta vaan myös rakentavat - ja pimittävät - maailmaamme: emme kielen avulla vain kuvaa tai tulkitse maailmaa vaan myös luomme ja tuotamme sitä. Sama pätee myös käsitevalintoihin: kiinnitymme eri käsitteitä käyttämällä erilaisiin teoria- ja tutkimusperinteisiin ja käsitteet voivat myös ohjata meitä kiinnittämään huomiomme ilmiössä johonkin sen tiettyyn puoleen tai aspektiin. 
Puheviestinnällä on paljon annettavaa kriisiviestinnän tutkimukselle ja opetukselle. Koska vuorovaikutuksen tarkastelu ihmisten välisen kanssakäymisen tasolla vaikuttaa tarpeelliselta mutta turhan harvakseltaan käytetyltä tulokulmalta kriisiviestinnän kentällä, ehdotan lopuksi kriisivuorovaikutuksen käsitteen nostamista kriisiviestinnän käsitteen rinnalle. Kriisivuorovaikutus vaikuttaa erityisen osuvalta käsitteeltä silloin, kun halutaan korostaa, ettei kyse ole vain yksisuuntaisesta kriiseistä tiedottamisesta tai uutisoinnista. Kriisivuorovaikutus on kaikkea sitä ihmisten välistä kanssakäymistä, vuorovaikutusta, jota ilmenee kriiseihin varautumisessa ja niiden estämisessä, kriisien hallinnassa ja niihin reagoinnissa sekä kriiseistä toipumisessa ja oppimisessa erilaisissa niin yksityis- kuin työelämän konteksteissa sekä laajemmissa yhteiskunnallisissa yhteyksissä niin yksilöiden, ryhmien kuin laajempien yhteisöjen ja verkostojen tasolla.

Puheviestinnän näkökulmien, kuten vuorovaikutusosaamisen käsitteen ja tutkimustradition, soveltaminen kriisiviestinnän tutkimukseen ja opetukseen on ollut äärimmäisen antoisaa. Kannustankin kaikkia puheviestijöitä jakamaan osaamistaan ja osallistumaan kriisiviestinnän monitieteisellä tutkimusalueella käytävään keskusteluun. Kriisiviestinnän lisäksi puheviestinnällä on lukuisia muita sovelluskohteita yhteiskunnassamme; puheviestinnän ymmärrystä tarvitaan kaikkialla, missä ihmiset ovat keskenään vuorovaikutuksessa. Puheviestintään kytkeytyy tieteenalana, oppiaineena ja ilmiönä valtava muutosvoima, ja parhaimmillaan puheviestintä voi olla mukana, kun ratkotaan isoja kansallisia ja kansainvälisiä kysymyksiä yksilöiden ja yhteisöjen hyvinvoinnista kansallisen kilpailukyvyn kehittämiseen sekä siirtolaisuudesta ja syrjäytymisen ehkäisemisestä kyberturvallisuuteen tai vaikkapa ympäristöasioihin vaikuttamiseen.
Miten puheviestinnän asiantuntemuksen soveltamista yhä uusille tai ainakin vähemmän käsitellyille elämänalueille voitaisiin sitten tukea? Miten löytää ja luoda "tiloja", joissa voitaisiin ehkä yllättäviäkin yhteyksiä huomaten ja hyödyntäen tuottaa innovatiivisia avauksia yhteiskuntamme suurten ja vähän pienempienkin kysymysten tarkasteluun? Jokainen voi toki pyrkiä itse pitämään mielensä avoimena uusille tutkimusideoille niin oman tieteenalan sisällä, rajoilla kuin ulkopuolella, mutta myös päättävässä asemassa olevat henkilöt voivat osaltaan tukea uusien yhteyksien löytymistä ja rajojen ylittämistä. Eräs konkreettinen vaihtoehto voisi olla "sekoittaa pakka hetkeksi" ja sijoittaa ihmisiä työhuoneisiin oppiaineiden ja tieteenalojen sijaan heitä kiinnostavien ilmiöiden perusteella, niin kuin Jyväskylän yliopiston uuden humanistis-yhteiskuntatieteellisen tiedekunnan tapaamisessa hiljattain ideoitiin. Tällöin kampuksella voisi vaikkapa viikon tai kuukauden ajan olla erityinen "Valtatalo", "Kriisikäytävä" tai "Maailmanparannussiipi", jonka asukkaita yhdistäisi kiinnostus samaan ilmiöön. Kenties uusia oivalluksia, yhteistyötä ja oppimista syntyisi myös menetelmien ympärille, jos ihmiset työskentelisivät hetken esimerkiksi "Diskurssitoimistoissa", "Delfoi-kulmauksissa" tai "Hermeneuttisilla ullakoilla"?

Puheviestinnän ymmärryksen soveltaminen yhä uusiin konteksteihin on tärkeää myös opetuksessa. Puheviestinnän opiskelijoilla on jo opintojensa aikana monenlaista vuorovaikutukseen liittyvää asiantuntemusta, jota voidaan edelleen kehittää pohtimalla yhdessä ryhmän kanssa, mitä annettavaa puheviestinnällä on tai voisi olla jossain tietyssä, kenties yllättävässäkin yhteydessä. Tämänkaltainen keskustelu voi auttaa opiskelijoita uudelleenhahmottamaan ja kielellistämään osaamisensa ydintä sekä puheviestinnän merkitystä eri elämänalueilla. Kokemukseni mukaan puheviestinnän asiantun- 
tijuuden ja jo olemassa olevan ymmärryksen soveltaminen uuteen kontekstiin yhdessä jo pidemmälle opinnoissaan edenneiden opiskelijoiden kanssa on parhaimmillaan äärimmäisen avartavaa kaikille - myös opettajalle yhtenä oppijana.

\section{Viitteet}

${ }^{1}$ Erityisen lämmin kiitos antoisista keskusteluista Helsingin yliopiston puheviestinnän syventävissä opinnoissa keväällä 2015 sekä Artevelde University College Ghentin viestinnän johtamisen ja journalistiikan laitoksella syksyllä 2015 tapaamilleni opiskelijoille.

\begin{abstract}
${ }^{2}$ Havainto perustuu kriisiviestinnästä tekemiini kirjallisuushakuihin sekä siihen, miten eri viestintätieteet ovat olleet viime aikoina edustettuina ECREAn, Eupreran, IAMCR:n, ICRC:n ja IDRC:n konferensseissa kriisiviestinnän työryhmissä: kriisejä lähestytään usein esim. organisaatioviestinnän tai uutisoitujen kriisien ja median näkökulmasta, kun taas ihmisten välisen vuorovaikutuksen näkökulma on harvemmin eksplisiittinen lähtökohta.
\end{abstract}

${ }^{3}$ Lisätietoa hankkeista:

http://www.crisiscommunication.fi.

${ }^{4}$ Lisätietoa esim. Wikipediasta: https://en.wikipedia. org/wiki/November_2015_Paris_attacks.

${ }^{5}$ Lisätietoa esim. Wikipediasta: https://en.wikipedia. org/wiki/Brussels_lockdown.

6 Lisätietoa esim. The Guardian -lehdestä: http://www.theguardian.com/world/2015/nov/22/ national-emergency-belgians-respond-with-cats.

\section{Kirjallisuus}

Austin, L., Liu, B. R. \& Jin, Y. 2012. How audiences seek out crisis information: exploring the socialmediated crisis communication model. Journal of Applied Communication Research 40 (2), 188-207.

Coombs, T. W. 2015. Ongoing crisis communication: planning, managing, and responding. 4. painos. Thousand Oaks: Sage.

Fearn-Banks, K. 2011. Crisis communications: a casebook approach. 4. painos. New York: Routledge.

Haataja, M., Hyvärinen, J. \& Laajalahti, A. 2014. Citizens' communication habits and use of ICTs during crises and emergencies. Human Technology:
An Interdisciplinary Journal on Humans in ICT Environments 10 (2), 138-152.

Hargittai, E., Fullerton, L., Menchen-Trevino, E. \& Thomas, K. 2010. Trust online: young adults' evaluation of web content. International Journal of Communication 4, 468-494.

Jensen, C. B. 2014. Continuous variations: the conceptual and the empirical in STS. Science, Technology \& Human Values 39 (2), 192-213.

Laajalahti, A. 2014. Vuorovaikutusosaaminen ja sen kehittyminen tutkijoiden työssä. Jyväskylän yliopisto. Jyväskylä Studies in Humanities 225.

Laajalahti, A., Hyvärinen, J. \& Vos, M. 2015. Perspectives on citizens' crisis communication competence in co-producing safety. Teoksessa E. Ordeix, V. Carayol \& R. Tench (toim.) Public relations, values and cultural identity. Lontoo: Peter Lang, 77-92.

Laajalahti, A., Hyvärinen, J. \& Vos, M. 2016. Crisis communication competence in co-producing safety with citizen groups. Social Sciences 5 (1), Art. 13.

Ojala, M. \& Saikkonen, S. 2014. Dikotomian tuolle puolen: teoretisointi tutkimuskäytäntönä. Media \& viestintä 37 (2), 89-95.

Reuter, C., Marx, A. \& Pipek, V. 2012. Crisis management 2.0: towards a systematization of social software use in crisis situations. International Journal of Information Systems for Crisis Response and Management 4 (1), 1-16.

Reynolds, B. \& Seeger, M. W. 2005. Crisis and emergency risk communication as an integrative model. Journal of Health Communication 10 (1), 43-55.

Ruggiero, A. \& Vos, M. 2014. Social media monitoring for crisis communication: process, methods and trends in the scientific literature. Online Journal of Communication and Media Technologies 4 (1), 105-130.

Taylor, M. \& Perry, D. C. 2005. Diffusion of traditional and new media tactics in crisis communication. Public Relations Review 31 (2), 209-217.

Ulmer, R. R., Sellnow, T. L. \& Seeger, M. W. 2015. Effective crisis communication: moving from crisis to opportunity. 3. painos. Thousand Oaks: Sage. 